\title{
UPAYA PENGEMBALIAN KERUGIAN NEGARA DARI PERKARA TINDAK PIDANA KORUPSI OLEH KEJAKSAAN NEGERI SUKOHARJO
}

\author{
Sara Hersriavita \\ Email :Cacasaramail@gmail.com \\ Mahasiswa Program Magister Ilmu Hukum Universitas Sebelas Maret \\ Lego Karjoko \\ Email :Legokarjoko@staff.uns.ac.id \\ Dosen Fakultas Hukum Universitas Sebelas Maret Surakarta \\ W.T Novianto \\ Email :widodotresnonovianto@staff.uns.ac.id \\ Dosen Fakultas Hukum Universitas Sebelas Maret Surakarta
}

\begin{abstract}
This paper aimed to study theasset recovery effort from corruption cases conducted by Sukoharjo State Prosecutor Office with public policy law study and law effectiveness study.Regarding its type, this paper was a problem solution research, as it seeks to find solutions that relate to the problems being studied, so that the type of paper is sociological with non-doctrinal / empirical approach. In this study using primary data sources, and secondary and tertiary as supporting data. Data collection techniques, researchers use interview techniques and library research (library research). Data analysis is by model of flow analysis (interactive model of analysis) and interactive analysis (interactive model of analysis). The results of paper and discussion although in returning the asset recovery from corruption cases in practice there are several inhibiting factors related to the legal effectiveness resulting in the return of the stolen state asset become not maximized, but the State Prosecutor Sukoharjo already implemented several policies related to the stolen state asset.
\end{abstract}

Keywords: Prosecutor Office; Asset Recovery; Corruption.

\begin{abstract}
Abstrak
Artikel ini mengkaji upaya pengembalian kerugian negara dari perkara tindak pidana korupsi yang dilakukan oleh Kejaksaan Negeri Sukoharjo dengan kajian hukum kebijakan publik dan studi keefektivitasan hukum.Berdasarkan jenisnya artikel ini merupakanproblem solution, karena berusaha untuk menemukan solusi yang berhubungan dengan permasalahan yang diteli, sehingga jenis artikel ini adalah artikel sosiologis dengan metode pendekatan non-doktrinal/empiris. Dalam artikel ini menggunakan sumber data primer, dan sekunder serta tersier sebagai data pendukungnya. Teknik pengumpulan data, menggunakan teknik wawancara dan studi kepustakaan (library research). Analisis data yaitu dengan model analisis mengalir (interactive model of analysis) maupun analisis interaktif (interactive model of analysis).Berdasarkan hasil artikel dan pembahasan meskipun dalam mengembalikan kerugian negara dari perkara tindak pidana korupsi dalam praktiknya terdapat beberapa faktor penghambat terkait dengan keefektivitasan hukum sehingga menyebabkan pengembalian kerugian negara tersebut menjadi tidak maksimal
\end{abstract}


namun, Kejaksaan Negeri Sukoharjo sudah menerapkan beberapa kebijakan terkait pegembalian kerugian Negara.

Kata Kunci: Kejaksaan; Pengembalian Kerugian Negara; Korupsi.

\section{A. Pendahuluan}

Perkembangan peradapan akhir-akhir ini kepentingan ekonomi manusia sangat tinggi, sehingga banyak manusia menginginkan cara yang praktis untuk memenuhi kebutuhan ekonomi yang sangat tinggi tersebut, akhirnya muncullah niat untuk memperkaya diri sendiri dengan memanfaatkan kekuasaan yang dimilikinya. Cara yang sangat modern saat ini menjadi masalah tersendiri di berbagai belahan dunia khususnya Indonesia adalah korupsi. Korupsi merupakan akibat dari sebuah situasi kondisi di mana seseorang membutuhkan penghasilan lebih, atau merasa kurang terhadap apa yang dia peroleh jika menjalankan usaha dengan cara-cara yang sah. Korupsi merupakan tindakan yang tidak lepas dari pengaruh kekuasaan dan kewenangan yang dimiliki oleh individu maupun kelompok, dan dilaksanakan baik sebagai kejahatan individu (professional) maupun sebagai bentuk dari kejahatan korporasi (dilakukan dengan kerjasama antara berbagai pihak (pelaku korupsi) yang ingin mendapatkan keuntungan sehingga membentuk suatu struktur organisasi yang saling melindungi dan menutupi keburukan masing-masing). Korupsi merupakan cerminan dari krisis kebijakan dan representasi dari rendahnya akuntabilitas birokrasi publik. Tindak pidana korupsi di Indonesia dari tahun ke tahun mengalami peningkatan jumlah kasusnya, kerugian negaranya, dan kualitas cara melakukannya. Faktor yang meyebabkan terjadinya korupsi baik berasal dari dalam diri pelaku, maupun dari luar pelaku. Bahwa ketika perilaku matrealistik dan konsumtif masyarakat serta sistem politik yang "masih mendewakan materi" maka dapat "memaksa" terjadinya permainan uang dan korupsi. Pemberantasan Korupsi, Kolusi dan Nepotisme (KKN) yang merupakan cita-cita reformasi dilakukan secara preventif dan represif.Korupsi yang menyebutkan bahwa salah satu unsur yang harus dipenuhi dalam mengungkap terjadinya tindak pidana korupsi adalah dapat merugikan keuangan negara atau perekonomian negara. (Moh Djafar Saidi, 2014 : 9).

Upaya yang dilakukan pemerintah dalam memberantas korupsi dilakukan diantaranya dengan penyempurnaan Undang-undang tentang Pemberantasan Korupsi dan pembentukan lembaga pemberantasan korupsi baru guna mendukung penegakan hukum. Pemerintah telah membentuk Undang-Undang Nomor 31 Tahun 1990 tentang Pemberantasan Tindak Pidana Korupsi menggantikan Undang-undang Nomor 3 Tahun 1971. Dua tahun kemudian untuk menyempurnakan Undang-undang Nomor 31 Tahun 1999, pemerintah mengeluarkan Undang-undang Nomor 20 Tahun 2001 tentang perubahan atas Undang-undang Nomor 31 Tahun 1999 tentang pemberantasan tindak pidana korupsi. Meskipun birokrasi pemerintahan Indonesia secara formal sudah disusun berdasarkan prinsip-prinsip adminitrasi negara yang modern, tetapi tidak berhasil mengendalikan praktik korupsi, kolusi, dan nepotisme diseluruh jajaran birokrasi. Hasil survei oleh transparansi Internasional terhadap 133 Negara menunjukkan Indonesia menduduki peringkat ke enam yang terkorup di dunia. (....Moh Djafar Saidi,2014 : 9).

Tidak dipungkiri bahwa Kejaksaan merupakan salah satu lembaga yang paling banyak disoroti ketika berbicara mengenai penegakan hukum di Indonesia. Kejaksaan sebagai 
ujung tombak penegakan hukum seringkali dituding tidak mampu melakukan pengawasan secara maksimal dan pembenahan atas aparat penegak hukum di internal Kejaksaan sendiri masih minim. Begitu banyak berita di masyarakat mengenai “permainan" para Jaksa dalam pemeriksaan suatu perkara, mulai dari penyimpangan perilaku hingga penanganan perkara yang tidak sesuai dengan ketentuan peraturan perundang-undangan. Sayangnya, kejaksaan sebagai institusi dipandang tidak mampu oleh masyarakat untuk membenahi permasalahan korupsi ini.

Langkah-langkah yang telah diakukan oleh Lembaga Kejaksaan dalam upaya pengembalian kerugian keuangan negara anatra lain dengan dikeluarkannya Surat Edaran Jaksa Agung Republik Indonesia SE-004/JA/8/1988 tentang pelaksanaan pembayaran uang pengganti, pada tahap penyidikan dalam rangka penyelamatan keuangan dan perekonomian negara akibat tindak pidana korupsi, jaksa penyidik semenjak dimulainya penyidikan wajib melakukan penyitaan yang dilakukan berdasarkan hasil penelitian yang cermat dari kegiatan penyidikan yang dilakukan. Selain itu lembaga kejaksaan adalah pengaturan mengenai penentuan tuntunan pidana yang diatur dalam Surat Edaran Jaksa Agung (SEJA) dengan nomor SE-003/A/JA/2010 Tentang Pedoman Tuntutan Pidana Tindak Pidana Korupsi Tertanggal 25 februari 2010 yang secara garis besar menyatakan bahwa apabila kerugian negara lebih dari $1 \mathrm{M}$. Pengembalian dalam tahapan penyidikan sebesar 75\% sampai dengan $100 \%$ maka pelaku akan dituntut 4 sampai dengan 4 tahun 6 bulan dan hal tersebut berlaku sebaliknya.

Unsur pengembalian kerugian negara menjadi salah satu unsur penting dalam eksekusi tindak pidana korupsi selain penjatuhan sanksi kepada para terdakwa. Penyelesaian kerugian negara perlu segera dilakukan untuk mengembalikan kekayaan negara yang hilang atau berkurang serta meningkatkan disiplin dan tanggung jawab para pegawai negeri/pejabat negara dan daerah pada umumnya, dan para pengelola keuangan pada khususnya hal ini tertuang dalam Undang-Undang Nomor 1 Tahun 2004. Pengelolaan keuangan negara merupakan satu hal yang vital yang memiliki dan mempunyai posisi penting dalam kehidupan berbangsa dan bernegara, karena sangat terkait dengan kemampuan negara mewujudkan tujuan bernegara. Pengelolaan keuangan negara jika dilakukan dengan baik dan maksimal akan dapat dipastikan memberi kekuatan bagi negara untuk berdiri tegak dan dengan otomatis memberi kesejahteraan pada rakyatnya, sebaliknya apabila penggunaan keuangan negara digunakan secara sewenang-wenang serta menjurus kepada praktik Korupsi, Kolusi, Nepotisme (KKN), maka akan berdampak timbulnya suatu permasalahan yang dapat menganggu kestabilitasan suatu sistem bernegara. Keuangan negara merupakan urat nadi dalam pembangunan suatu negara dan amat sangat menentukan kelangsungan perekonomian baik sekarang maupun yang akan datang. (Andrian Sutendi, $2010: 10$ )

Sejak tahun 2012 sampai dengan bulan april 2017, perkara tindak pidana korupsi yang ditangani oleh Kejaksaan Negeri Sukoharjo sebanyak 16 perkara yang menimbulkan kerugian keuangan negara kurang lebih sebesar Rp. Rp.21.123.966.993,00 (Dua puluh satu milyar seratus dua puluh tiga juta sembilan ratus enam puluh enam sembilan ratus sembilan puluh tiga rupiah).Dari 16 perkara tersebut sebanyak 6 (enam) perkara telah dapat diselamatkan dalam hal kerugian negara sebesar Rp. 4.042.261.137,00 (empat milyar empat puluh dua juta dua ratus enam puluh satu ribu seratus tiga puluh tujuh rupiah), jumlah ini tentu sangat jauh dari kerugian awal maka, penulis tertarik untuk mengkaji apa saja hal-hal yang 
menyebabkan tidak maksimalnya pengembalian kerugian negara dari perkara tindak pidana korupsi serta upaya apa yang dilakukan Kejaksaan Negeri Sukoharjo dalam menghadapi faktor penghambat tersebut.

\section{B. Metode Penelitian}

Artikel ini dilakukan di Kejaksaan Negeri Sukoharjo.Artikel ini menggunakan metode pendekatan non doktrinal/empiris, dengan jenis pendekatan kualitatif, menurut sifatnya adalahdeskriptif. Sumber dan jenis data yaitu data Primer dan sekunder.Data primer dalam artikel ini diperoleh melalui wawancara yang tidak terstruktur dengan beberapa narasumber yaitu dengan memberikan pertanyaan yang menunjukkan keprihatinan, penjagaan, kerjasama yang pada akhirnya informan berpartisipasi untuk memberikan informasi (HB Sutopo,2002: 99-101)Data sekunder yaitu mencangkup mengenai buku-buku, dokumen resmi, hasil-hasil penelitian terdahulu yang berwujud laporan, dan sebagainya. (Amiruddin dan Zainal Asuikin, $2004: 30)$.

\section{Hasil Penelitian dan Pembahasan}

\section{Faktor-Faktor yang Menyebabkan Tidak Maksimalnya Pengembalian Kerugian Negara dari Perkara Tindak Pidana Korupsi Di Kejaksaan Negeri Sukoharjo.}

Korupsi mempunyai pengaruh yang paling menghancurkan di negara-negara yang sedang mengalami transisi seperti Indonesia. Korupsi merupakan masalah yang mengganggu dan menghambat pembangunan nasional karena korupsi telah mengakibatkan terjadinya kerugian keuangan negara. Korupsi juga dapat melemahkan sendi-sendi kehidupan di dalam masyarakat, berbangsa, dan bernegara, untuk itu diperlukan eksekusi tindak pidana korupsi secara maksimal oleh instansi Kejaksaan, khususnya dalam penelitian ini Kejaksaan Negeri Sukoharjo. Sesuai dengan teori keefektifan hukum yang dikemukakan oleh Soerjono Soekanto bahwa efektif atau tidaknya suatu hukum ditentukan oleh 5 (lima) faktor, yaitu :(Soerjono Soekanto, 2008: 8)

1. Faktor hukumnya sendiri (undang-undang).

2. Faktor penegak hukum, yakni pihak-pihak yang membentuk maupun menerapkan hukum.

3. Faktor sarana atau fasilitas yang mendukung penegakan hukum.

4. Faktor masyarakat, yakni lingkungan dimana hukum tersebut berlaku atau diterapkan.

5. Faktor kebudayaan, yakni sebagai hasil karya, cipta dan rasa yang didasarkan pada karsa manusia di dalam pergaulan hidup.

Soerjono Soekanto mengatakan bahwa efektif adalah taraf sejauh mana suatu kelompok dapat mencapai tujuannya. Hukum dapat dikatakan efektif jika terdapat dampak hukum yang positif, pada saat itu hukum mencapai sasarannya dalam membimbing ataupun merubah perilaku manusia sehingga menjadi perilaku hukum. Sehubungan dengan persoalan efektivitas hukum, pengidentikkan hukum tidak hanya dengan unsur paksaan eksternal namun juga dengan proses pengadilan. Ancaman paksaan pun merupakan unsur yang mutlak ada agar suatu kaidah dapat dikategorikan sebagai hukum, maka tentu saja unsur paksaan inipun erat kaitannya dengan efektif atau tidaknya suatu ketentuan atau aturan hukum. Berdasarkan hasil wawancara yang 
dilakukan di Kejaksaan Negeri Sukoharjo diperoleh faktor-faktor yang menyebabkan kerugian keuangan negara sebagai berikut :

\section{a. Faktor Substansi Hukum.}

1) Minimnya aturan mengenai uang pengganti dalam Undang-Undang Nomor 31 Tahun 1999 jo Undang-Undang Nomor 20 Tahun 2001 tentang Pemberantasan Tindak Pidana Korupsi.

Faktor mengenai minimnya aturan tentang uang pengganti mengakibatkan Timbulnya kerancuan pada penerapnnya. Sebagaimana diketahui UndangUndang Pemberantasan Tindak Pidana Korupsi Nomor 31 tahun 1999 yang diubah dengan Undang-Undang Pemberantasan Tindak Pidana Korupsi Nomor 20 Tahun 2001 hanya mengatur pidana tambahan pembayaran uang pengganti dalam satu pasal, yaitu Pasal 18, dengan poin-poin aturan yang hanya mencakup 3 (tiga) hal, yaitu: pertama, bagaimana menghitung besaran uang pengganti; kedua, kapan uang pengganti selambatnya dibayarkan; dan ketiga, bagaimana konsekuensinya jika uang pengganti tidak dibayar. Ketentuan sanksi pidana mengenai pembayaran uang pengganti dalam Pasal 18 ayat (3) UndangUndang Pemberantasan Tindak Pidana Korupsi Nomor 31 Tahun 1999 kurang menguntungkan bagi negara. Pengaturan uang pengganti dalam Undang-Undang Pemberantasan Tindak Pidana Korupsi Nomor 3 Tahun 1971, dan UndangUndang Pemberantasan Tindak Pidana Korupsi Nomor 31 Tahun 1999 sama dengan Undang-Undang Pemberantasan Tindak Pidana Korupsi sebelumnya yaitu uang pengganti jumlah keseluruhan sebanyak-banyaknya sama dengan harta benda yang diperoleh sebagai hasil korupsi.

Perihal mengenai minimnya pengaturan pidana uang pengganti ini selanjutnya berimplikasi kepada siapa yang berwenang mengelola dana hasil sitaan dari para koruptor. Ketidakjelasan mengenai mekanisme pengelolaan uang ini telah menimbulkan dugaan bahwa dana yang telahberhasil diselamatkan malah dikorupsi kembali oleh lembaga penegak hukum yang mengeksekusi, dalam hal ini Kejaksaan. (Ismansyah, 2007 : 43)

Hal terkait penanganan perkara korupsi perihal uang penggantian maka seharusnya pasal 18 ayat 3 tersebut dapat dianulir dengan tidak memberikan pidana penjara kepada para terpidana tetapi tetap memberikan beban uang pengganti kepada anak, isteri atau siapapun yang itu kebagian dan terlibat dalam tanggungan utang negara tersebut hal tersebut yang menyebabkan pegembalian kerugian negara tidak bisa maksimal.

2) Pengaturan dalam pasal 18 Undang-Undang Pemberantasan Korupsi kurang tegas dalam penerapannya.

Pengaturan dalam pasal 18 ayat (2) ini frasa yang berbunyi "dapat disita oleh jaksa dan dilelang untuk menutupi uang pengganti tersebut" seharusnya kata "dapat" diganti kata "wajib" jadi Jaksa dalam melakukan eksekusinya bisa dengan tegas segera melakukan penyitaan dan pelelangan supaya penyelamatan kerugian negara dapat maksimal. 
3) Undang-undang korupsi secara khusus tidak mengatur mengenai penyitaan.

Aturan mengenai penyitaan yang diatur dalam Undang-Undang Pemberantasan Tindak Pidana Korupsi Nomor 31 Tahun 1999 Jo UndangUndang Nomor 20 Tahun 2001 pada pasal 26 menyebutkan bahwa penyidikan, penuntutan dan pemeriksaan disidang pengadilan dilakukan berdasarkan hukum acara pidana yang berlaku, kecuali ditentukan lain dalam undang-undang ini. Undang-undang Pemberantasan Tindak Pidana Korupsi Nomor 31 Tahun 1999 Jo Undang-Undang Nomor 20 Tahun 2001 tidak mengatur secara khusus hal-hal tentang penyitaan padahal Undang-Undang sebagai Lex Specialis, maka untuk melakukan penyitaan harus merujuk pada Kitab Undang-Undang Hukum Acara Pidana sebagai Lex Generalisnya.

\section{b. Faktor Penegak Hukum.}

1) Penyidik kurang melakukan koordinasi.

Penyidikan yang dilakukan oleh Penyidik Kejaksaan Negeri Sukoharjo dengan Penyidik pihak lain (diluar penyidik Kejaksaan Negeri Sukoharjo) kurang adanya koordinasi sehingga terjadi tumpang tindih penyidikan yang justru membuat proses penyidikan menjadi terhambar dan pelaksaan yang kurang cermat, karena penelurusan hanya dilakukan untuk menelurusi harta kekayaan yang berupa dokumen atau surat-surat resmi, tidak terhadap harta benda yang mungkin dapat disita.

2) Penyidikan yang dilakukan dalam waktu yang lama.

Penyidikan yang memakan waktu lama membuat para pelaku tindak pidana korupsi semakin jeli dan licik untuk mewaspadai penyidikan sehingga mereka dengan cepat menyelamatkan harta benda hasil perkara tindak pidana korupsi entah dengan dipindah tangankan atau dengan melarikannya ke luar negeri.

3) Penyidik tidak melakukan proses pelacakan asset terlebih dahulu sebelum semua asset terdakwa dengan sigap segera dipindah tangankan.

\section{c. Faktor sarana dan Prasarana.}

1) Faktor yang menjadi penghambat adalah faktor operasional mengenai kelengkapan alat (alat sadap, alat pelacak) dan dana untuk penanganan kasus tindak pidana korupsi yang jauh lebih sedikit dengan yang dimiliki oleh Komisi Pemberantasan Korupsi.

Contohnya dalam hal mencari dan menemukan aset harta kekayaan itu dibutuhkan biaya yang tidak sedikit apalagi kalau tersangkanya lari ke luar negeri, sebenarnya pada saat melakukan penyidikan para Jaksa di Kejaksaan Negeri Sukoharjo sudah memikirkan mengenai pengembalian kerugian keuangan negara tetapi dalam praktiknya tidak mudah untuk dilakukan penyitaan mengingat terpaku pada suatu peraturan perundang-undangan diharapkan tetap pada jalurnya sehingga tidak salah dalam mengambil sikap, maka hal itu yang 
menyebabkan tidak maksimalnya pengembalian kerugian keuangan negara dalam perkara tindak pidana korupsi, kemudian untuk eksekusi uang pengganti (aset recovery) yang menjadi kewenang pidana khusus hanya dibekali mengenai teknik PPA (Pusat Pemulihan Aset) saja namun tidak disediakan dana yang cukup untuk proses tersebut tetapi Kejaksaan Negeri Sukoharjo tetap mengusahakan PPA tersebut meki dengan dana yang sedikit.

2) Prosedur ijin yang sulit.

Sarana dan prasarana berupa ijin yang sulit dan prosedur yang sangat panjang untuk dapat menembus tentang kerahasiaan bank sebelum melakukan penyitaan terhadap uang/dana yang ada dalam rekening tersangka pada suatu bank juga merupakan faktor yang menjadi alasan tidak maksimalnya pengembalian kerugian negara dari perkara tindak pidana korupsi. Kejadian dilapangan yang ditemui adalah jaksa penyidik pada tingkat kejaksaan negeri tidak bisa langsung mengajukan permohonan ijin pemeriksaan rekening tersangka kepada Gubernur Bank Indonesia, tetapi permintaan ijin harus dilakukan melalui Jaksa Agung sehingga hal itu tentu saja akan memakan waktu yang cukup panjang, dengan waktu yang lama tersebut dikhawatirkan seorang tersangka sudah mengetahui dan mencurigai kemungkinan tindakan penyidik yang akan melakukan tindakan penyitaan terhadap uang yang disimpan pada suatu bank sehingga mereka berlaku licik untuk segera memindahkan uang tersebut.

\section{d. Faktor Masyarakat.}

Sebagai penutup dalam melakukan penelitian lapangan dimana objeknya adalah langsung dari Kejaksaan Negeri Sukoharjo yang dilengkapi dengan data lapangan berupa hasil wawancara penulis mewawancari Kepala Seksi Tindak Pidana Khusus Kejaksaan Negeri Sukoharjo yaitu bapak Zaenurofiq,SH yang menyatakan bahwafaktor kecil yang berpengaruh adalah masyarakat, peran serta masyarakat yang sedikit apatis dengan tidak peduli apabila disekitar mereka terdapat perilaku yang terindikasi kasus korupsi mereka enggan melaporkan dan bersifat "yaudahlah bukan urusan saya, yang penting kalo ketahuan korupsi ya harus dihukum berat", itu juga menjadi salah satu penghambat bagi Kejaksaan Negeri Sukoharjo. Lalu asumsi masyarakat bahwa pelaku tindak pidana korupsi harus dihukum seberatberatnya tanpa mengetahui dan memikirkan perihal kerugian keuangan negara dari hasil tindak pidana korupsi tersebut.

Kelemahan lainnya yang menjadi kendala dalam pemberantasan korupsi adalah tidak dintensifkannya tindakan pencegahan. Seperti diketahui bersama, banyak lembagalembaga yang dibentuk untuk memerangi korupsi, mulai dari operasi militer (1957), TimPemberantasan Korupsi (1967), hingga Komisi Pemeriksaan Kekayaan Penyelenggara Negara (1999) sampai dengan pembentukan Tim Gabungan Pemberantasan Tindak Pidana Korupsi. Tetapi hasilnya korupsi tetap tidak bisa diberantas, bahkan semakin terang-terangan. (KPK, 2005) 


\section{Upaya yang Di Lakukan Oleh Kejaksaan Negeri Sukoharjo Dalam Memaksimalkan Pengembalian Kerugian Negara dari Perkara Tindak Pidana Korupsi.}

Upaya pengembalian kerugian negara akibat tindak pidana korupsi, berarti berbicara mengenai upaya penegakan hukum dalam upaya menagnggulangi kejahatan korupsi khususnya kemampuan mengembalikan kerugian negara yang dikorupsi. Oleh karena itu diperlukan upaya yang kompreherensif untuk menanggulanginya yaitu melakukan upaya pengembangan sistem hukum, karena pada dasarnya korupsi merupakan kejahatan sistemik yang berkaitan erat dengan kekuasaan. (Indriyanto Seno Adji, 2001 : 236), Upaya pengembalian aset negara 'yang dicuri' (stolen asset recovery) melalui tindak pidana korupsi cenderung tidak mudah untuk dilakukan. Para pelaku tindak pidana korupsi memiliki akses yang luar biasa luas dan sulit dijangkau dalam menyembunyikan maupun melakukan pencucian uang (money laundering) hasil tindak pidana korupsi. (Eddy OS Hieriej, $2013: 2$ )

\section{a. Melalukan pembenahan pada substansi hukum.}

Menyangkut pembaharuan terhadap berbagai perangkat peraturan perundangundangan atau ketentuan normatif, dalam konteks upaya memaksimalkan pengembalian kerugian negara hasil korupsi perlu dilakukan re-evaluasi tentang adanya ketentuan mengenai aturan pidana pengganti (subsidair). (Rudi Pardede, 2016 : 134).

Berlakunya Undang-Undang Tata cara pelaksanaan Uang Pengganti dari 2 sumber hukum, dilihat dari Undang-Undang No.3 Tahun 1971 maka mekanismenya ialah dengan cara ditagih melalui gugatan perdata yang dilimpahkan kepada jaksa Datun apabila tidak sanggup bayar. Apabila terpidana sungguh sungguh tidak mampu membayar uang pengganti, maka tugas jaksa selaku eksekutor yakni untuk melakukan pelacakan aset berupa mencari serta meminta bantuan kepada aparat setempat untuk memberikan keterangan maupun bukti bahwa terpidana benar-benar tidak memiliki harta untuk membayar Uang pengganti, setelah itu kewajiban terpidana untuk membuat surat keterangan tidak mampu membayar Uang Pengganti. Namun sesuai dengan prinsip hukum perdata, yakni walaupun telah dihapus bukukan piutangnya, hutang tersebut tidak akan hilang. Undang-undang Nomor 31 Tahun 1999 yang telah diubah dengan Undang Undang Nomor 20 Tahun 2001, mekanisme penagihannya apabila terpidana tidak mampu membayardalam jangka satu bulan setelah putusan berkekuatan hukum tetap, maka diganti dengan pidana subsider kurungan badan (penjara). Uang pengganti yang belum terbayarkan oleh terpidana dianggap telah dibayar apabila terpidana sudah menjalani hukuman subsider kurungan badan tersebut. Upaya tersebut dilakukan secara maksimal sehingga diharapkan dapat memaksimalkan pula penyelamatan kerugian negara.

\section{b. Melakukan pembenahan pada penegak hukum.}

Meliputi perbaikan segala kelembagaan atau organ-organ yang menyelenggarakan peradilan sehingga dapat meminimalisir terjadinya korupsi. Khusus untuk penegak hukum mereka harus menggunakan cara luar biasa dalam menangani kasus-kasus korupsi karena korupsi sebagai kejahatan extra ordinary crime yaitu dengan cara memaksimalkan upaya penyelidikan dan penyidikan untuk mencari aset negara 
yang dikorupsi oleh terdakwa. (...Rudi Pardede, 2016 : 134).Langkah-langkah yang dilakukan kejaksaan dalam upaya tersebut adalah:

a) Pelacakan aset (asset tracking)

b) Pembekuan aset (freezing)

c) Penyitaan aset (confiscation forfeiture asset)

d) Pengembalian aset melalui tuntutan pidana yang ditindak lanjuti dengan putusan pengadilan dengan memperoleh kekuatan hukum tetap.

Disamping langkah-langkah tersebut Kejaksaan juga melakukan beberapa tahapan lain sebagai berikut :

1) Tahap Penyidikan. Dalam rangka penyelamatan keuangan dan perekonomian negara dalam perkara tindak pidana korupsi, jaksa penyidik semenjak dimulainya penyidikan wajb melakukan penyitaan terhadap harta benda tersangka, istri/suami, anak dan setiap orang yang mempunyai hubungan dengan perkara tersangka. Penyitaan ini dilakukan berdasarkan hasil penelitian yang cermat dari kegiatan-kegiatan penyidikan yang dilakukan sebelumnya.

2) Tahap Penuntutan. Jaksa/ penuntut umum dalam tuntutan pidananya wajib meminta kepada hakim agar menjatuhkan pidana tambahan berupa pembayaran uang pengganti disamping pidana pokok dan menyatakan merampas barang yang diista dalam tahap penyidikan. Nilai dari keseluruhan barang-barang yang dimohonkan untuk dirampas dan jumlah tuntutan pembayaran uang pengganti adalah sebanyak-banyaknya sama dengan harta benda yang diperoleh dari tindak pidana korupsi.

3) Tahap Eksekusi. Dalam rangka melaksanakan putusan hakim jika pembayaran uang pengganti belum mencukupi, jaksa eksekutor melakukan penyitaan terhadap harta benda lainnay daripada terpidana tanpa memerlukan campir tangan pihak pengadilan dalam bentuk penyitaan yang dituangkan dalam bentuk penetapan, dan lain-lain.

Dari uraian diatas dapat diketahui bahwa Kejaksaan mempunyai kewenangan dan bisa memaksimalkan perannya dalam upaya pengembalian kerugian keuangan negara akibat tindak pidana korupsi pada semua tingkat pemeriksaan, mulai dari penyidikan, penuntutan sampai pada tahap pelaksanaan putusan pengadilan/eksekusi.

\section{c. Budaya Hukum Masyarakat}

Pihak kejaksaan harus dapat menggalang jaringan yang luas, berani bersinergi dengan aparat penegak hukum lain seperti KPK dan Kepolisian serta dapat meyakinkan kepada masyarakat bahwa mereka harus lebih berani melaporkan para koruptur, dengan melakukan penyuluhan gerakan anti korupsi di tingkat Lembaga Swadaya Masyarakat (LSM), organisasi, mahasiswa dan organisasi kemasyarakat lainnya sebagai civil society.

Partisipasi aktif masyarakat sangat diperlukan dalam upaya pemberantasan kasus tindak pidana korupsi, setidak-tidaknya masyarakat memiliki inisiatif apa adanya kecurigaan terhadap adanya penambahan aset kekayaan penyelenggaraan negara yang berada di lingkungan Kejaksaan Negeri Sukoharjo sehingga memudahkan 
aparat penegak hukum melakukan pelacakan dan pembekuan bilamana tindakan tersebut terbukti mengarah kepada tindak pidana korupsi.

Upaya lain yang dilakukan adalah dengan menerapkan kebijakan kepada Jaksa yang menangani kasus korupsi untuk terus dan selalu melakukan perbaikan, pembenahan dan koordinasi yang utuh agar dapat menyelaraskan kepastian hukum dalam pekara tindak pidana korupsi, sesuai dengan teori yang dikemukakan oleh Merile S Grindle (1980) bahwa dalam berhasil tidaknya kebijakan itu dipengaruhi oleh beberapa kegiatan seperti(AG Subarsono, 2016 : 93-94):

a) Kepentingan yang dipengaruhi oleh kebijakan

Kejaksaan berkewajiban untuk menyelamatkan kerugian negara dalam perkara tindak pidana korupsi selain Komisi Pemberantasan Korupsi, ternyata apa yang dialami oleh Kejaksaan Negeri Sukoharjo banyak menemui beberapa faktor penghambat dimana faktor utama adalah berasal dari internal dari pelaku tindak pidana korupsi itu sendiri, maka dengan adanya faktor kelicikan pelaku untuk menyembunyikan harta kekayaannya ini dibentuklah pelatihan Pusat Pemulihan Aset (PPA) oleh Kejaksaan Agung yang diikuti oleh Kejaksaan Negeri Sukoharjo khususnya bagian Tindak Pidana Khusus. Kerugian negara harus dikembalikan kepada negara karena negara selaku pemilik kekayaan.

b) Manfaat yang dihasilkan

Penerapan kebijakan dibentuknya Pusat Pemulihan Aset akan sangat membantu karena dapat mengoptimalkan pemulihan aset terkait hasil kejahatan atau aset lainnya secara efektif, efisien, transparan, akuntabel, secara terintegrasi dengan pola sistem pemulihan aset terpadu, melaksanakan pendampingan terhadap satuan kerja di Kejaksaan Republik Indonesia maupun kementrian lembaga lain, mengembangkan sistem database pemulihan aset yang secured dan terintegrasi.

c) Perubahan yang diinginkan

Perubahan yang diinginkan dengan adanya kebijakan Pusat Pemulihan Aset ini adalah kekayaan hasil korupsi dapat dicegah untuk tidak digunakan kegiatan lainnya, mencegah kerugian negara yang signifikan, untuk meningkatkan martabat bangsa Indonesia di forum Internasional, mewujudkan keadilan sosial bagi seluruh rakyat Indonesia. Di Indonesia sendiri upaya pemberantasan tindak pidana korupsi sudah ada sejak zaman Belanda sebagaimana yang diatur oleh Pasal-Pasal 209, 210, 387, 388, 415, 416,417, 418, 419, 420, 423, 435 dalam Kitab Undang-Undang Hukum Pidana namun sejak tahun 1971 baru adanya Lex Specialis Derogate Lege Generalis tentang Tindak Pidana Korupsi yaitu: Pertama, Undang-Undang Republik Indonesia Nomor 3 Tahun 1971 Tentang Tindak Pidana Korupsi (Lembaran Negara Republik Indonesia 1971 Nomor 19) yang di sahkan pada tanggal 29 Maret tahun 1971. Saat ini sudah dicabut tidak berlaku lagi; Kedua, Undang-Undang Republik Indonesia Nomor 31 Tahun 1999 Tentang Pemberantasan Tindak Pidana Korupsi (Lembaran Negara Republik Indonesia Tahun 1999 Nomor 140 dan Tambahan Lembaran Negara Republik Indonesia 3874) atau disebut Undang-Undang Nomor 31 tahun 1999; Ketiga 
Undang-Undang Republik Indonesia Nomor 20 Tahun 2001 Tentang Perubahan Atas Undang-Undang Nomor 31 Tahun 1999 Tentang Pemberantasan Tindak Pidana Korupsi (Lembaran Negara Republik Indonesia Tahun 2001 Nomor 134 dan Tambahan Lembaran Negara Republik Indonesia 4150) atau disebut Undang-Undang Nomor 20 tahun 2001; Keempat, Undang-Undang Republik Indonesia Nomor 7 Tahun 2006 Tentang Pengesahan United Nations Convension Against Corruption,tahun 2003 atau Konvensi Perserikatan Bangsa-Bangsa Anti Korupsi, tahun 2003 (Lembaran Negara Republik Indonesia Tahun 2006 Nomor 32 dan Tambahan Lembaran Negara Republik Indonesia 4620) atau disebut Undnag-Undang Nomor 7 tahun 2006 tetapi Indonesia juga tak kunjung bebas dari korupsi, maka dengan adanya upaya ini diharapkan mampu mencapai derajat perubahan yang diinginkan bangsa.

d) Kedudukan pembuat kebijakan

Kebijakan Pusat Pemulihan Aset ini dibuat oleh Jaksa Agung dan diikuti oleh Kejaksaan Negeri seluruh wilayah Republik Indonesia khusunya bagian tindak pidana khusus.

e) Pelaksana

Upaya pemberantasan korupsi tidak henti-hentinya dilakukan oleh Pemerintah Republik Indonesia ini, mulai dari Kepolisian, Kejaksaan dan Komisi Pemberantasan Korupsi, namun hanya pemberantas korupsi itu sebatas deret hitung sampai detik ini tetap belum bisa maksimal. Sehingga sampai kapanpun tindak pidana korupsi di Indonesia tidak bisa dihapuskan, lebih banyak pelaku tindak pidana korupsi dari pada pelaku pelaksana pemeberantasan maka dibentuklah pelatihan Pusat Pemulihan Aset ini. Pusat Pemulihan Aset ini dilaksanakan oleh Kejaksaan Negeri seluruh wilayah Republik Indonesia serta dukungan masyarakat untuk dapat mengupayakan semaksimal mungkin pengembalian kerugian negara dalam tindak pidana korupsi.

f) Sumber daya

Berhasil tidaknya suatu kebijakan juga dipengaruhi oleh adanya sumber daya, maka untuk memaksimalkan pengembalian kerugian negara yang ada, lingkup Kejaksaan Negeri harus memaksimalkan potensi sumber daya yang ada didalam Kejaksaan tersebut.

Merile S Grindel (1980)(...AG Subarsono, 2016 : 93-94)juga mengemukan dalam konteks implementasi suatu kebijakan dapat terlaksana dengan baik karena:

a) Kekuasaan, Kepentingan dan Strategi aktor yang terlibat.

Ketua Mahkamah Agung Republik Indonesia berdasarkan Surat Edaran Mahkamah Agung Republik Indonesia Nomor 12 Tahun 2010 Tentang Penjatuhan Pidana yang berat dan Setimpal dalam Tindak Pidana Korupsi, tanggal 27 September 2010 meminta kepada semua hakim di Republik Indonesia di semua tingkatan agar dalam menjatuhkan putusan pemidanaan yang tepat 
dan setimpal tidak hanya sekedar menjatuhkan pidana minimal, dengan acuan pada kadar perbuatan terdakwa dan potensi kerugian negara yang diakibatkan perbuatan negara.

Pengembalian kerugian negara dari hasil korupsi masih sangat jauh dari harapan bangsa Indonesia, sehingga upaya dalam mengembalikannya harus dilakukan semaksimal mungkin, maka diperlukan strategi dari seluruh satuan aparat penegak hukum khususnya Kejaksaan dimana Jaksa bertindak sebagai penuntut umum, dan eksekutor dalam kasus tindak pidana korupsi. Selama ini kasus yang terjadi di Indonesia dalam menangani perkara korupsi cenderung terfokus pada penghukuman terhadap pelaku tindak pidana korupsi daripada pegembalian kerugian negara maka, dibutuhkan strategi darin para pemegang kekuasaan, dan kepentingan dalam hal ini adalah Jaksa.

b) Karakteristik lembaga dan penguasa.

Lembaga yang berkuasa menangani kasus korupsi ialah Komisi Pemberantasan Korupsi, Kejaksaan serta Kepolisian, berhasil tidak nya suatu kebijakan dipengaruhi oleh korelasi dari ketiga lembaga tersebut. Bahwa pada kenyataannya dalam pelaksanaan kewenangan penuntutan oleh Kejaksaan sering timbul permasalahan antar lembaga penegak hukum lainnya dalam hal: koordinasi berkas perkara antara Kejaksaan dan penyidik Kepolisian pada tahap prapenuntutan, pertanggungjawaban penguasaan penahanan antara Kejaksaan dan Pengadilan terhadap status pengalihan penahanan selama pemeriksaan di persidangan dan peralihan pada saat pelimpahan berkas perkara ke pengadilan. dualisme kewenangan penuntutan antara Kejaksaan dan KPK terhadap perkara tindak pidana korupsi, hal ini sesuai dengan isi dari artikel Pusat Litbang Kejaksaan Agung R.I, Studi tentang Manajemen Penanganan Perkara Tindak Pidana Korupsi Di Indonesia dan Kewenangan Aparat penegak Hukum Dari KPK, Kejaksaan dan Kepolisian tahun 2008, meskipun demikian lembaga penguasa Kejaksaan sejauh ini sudah mengupayakan banyak hal untuk menyelematkan kerugian negara contohnya Kejaksaan Agung telah dibentuk adanya Asset Recovery (pemulihan Aset) adalah proses penanganan aset hasil kejahatan yang dilakukan secara terintegrasi disetiap tahap penegakan hukum, sehingga nilai aset tersebut dapat dipertahankan dan dikembalikan seutuhnya kepada korban kejahatan, termasuk korbannya adalah Negara Indonesia. Pemulihan aset juga meliputi segala tindakan yang bersifat preventif untuk menjaga agar nilai aset tersebut tidak berkurang. Lembaga penguasa diharapkan mempunyai karakteristik dalam penanganan tindak pidana korupsi dengan tidak hanya berdalih pada undang-undangnya saja tetapi juga fokus kepada bagaimana pengembalian kerugian negara dari hasil korupsi tersebut.

\section{Simpulan}

1. Pengembalian kerugian keuangan negara oleh Kejaksaan Negeri Sukoharjo selama tahun 2012 hingga bulan Juli 2017 dapat dikatakan belum berhasil dalam pelaksanaannya, hal ini dilihat dari total jumlah kerugian selama lima tahun terakhir sebesar Rp.21.123.966,00 
tetapi yang dapat diselamatkan hanya sebesar Rp.4.042.261.137,00 hanya sekitar 20\% dari total kerugian. Kendati demikian, karena Kejaksaan Negeri Sukoharjo mengalami beberapa faktor yang menghambat dan menyebabkan tidak maksimalnya pengembalian kerugian keuangan negara di antaranya faktor internal : faktor substansi hukum, faktor penegak hukum, faktor eksternal meliputi : Sarana dan fasilitas yang mendukung kurang memadai, masyrakat yang acuh dan cenderung tidak peduli dengan indikasi perkara korupsi disekitarnya.

2. Upaya yang dilakukan Kejaksaan Negeri Sukoharjo dalam memaksimalkan pengembalian kerugian negara dalam perkara Tindak Pidana Korupsi adalah melakukan beberapa hal sebagai berikut :

Pembenahan dari substansi hukum itu sendiri dengan harapan bahwa ada ketegasan dan peningkatan kualitas produk hukum yang digunakan jaksa sebagai pedoman dalam eksekusi perkara korupsi yang erat kaitannya dengan pengembalian kerugian keuangan negara, Pembenahan dari aspek penegak hukum dengan melakukan koordinasi dengan berbagai sumber pelaksana hukum dan sasaran kepada masyarakat sebagai tujuan kebijakan dalam upaya pengembalian kerugian keuangan negara mengoptimalkan mekanisme proses penyidikan dengan koordinasi dengan berbagai pihak terkait, penjabaran tujuan kedalam berbagai aturan pelaksanaan (SOP).

\section{E. Saran}

Berdasarkan kesimpulan diatas peneliti memberikan saran-saran sebagai masukan untuk dikemudian hari, sebagai berikut :

1. Kejaksaan Negeri Sukoharjo agar dapat lebih membangun komitmen dengan jajaran penyidik diluar kejaksaan di daerah hukum setempat guna keberhasilan proses penyidikan dan demi memaksimalkan pengembalian keuangan negara sehingga kinerja keduanya dapat optimal tidak terjadi tumpang tindih.

2. Kejaksaan melakukan koordinasi dengan pemerintah pusat untuk melakukan upaya legislasi yang merupakan upaya yang dilakukan oleh pemerintah untuk menekan terjadinya suatu masalah dengan menugaskan lembaga-lembaga negara yang memiliki kewenangan-kewenangan yang diberikan oleh undang-undang. Upaya legislasi tersebut diharap dapat menekan jumlah kerugian keuangan negara.

3. Jaksa hendaknya lebih teliti dan cermat dalam melakukan proses penyitaan atau penyelidikan seperti yang dilakukan oleh Komisi Pemberantasan Korupsi.

\section{F. Daftar Pustaka}

\section{Buku-buku}

AG Subarsono. 2016. Analisa Kebijakan Publik Konsep, Teori, dan Aplikasi. Yogyakarta : Pustaka Pelajar.

Amiruddin dan Zainal Asuikin.2004.Pengantar Metode Penelitian Hukum.Jakarta.: PT. Raja Grafindo Persada 
Andrian Sutendi. 2010. Hukum Keuangan Negara. Jakarta : Sinar Grafika.

HB Sutopo.2002.Metodologi Penelitian Kulaitatif.Surakarta : UNS Press.

Indriyanto Seno Adji. 2001. Korupsi dan Hukum Pidana. Jakarta.

Moh Djafar Saidi. 2014. Hukum Keuangan Negara.Jakarta : PT.Raja Grafindo Persada.

Rudi Pardade. 2016. Proses Pengembalian Kerugian Negara Akibat Korupsi. Yogyakarta: Genta Publishing.

Soerjono Soekanto. 1998. Faktor-Faktor yang Mempengaruhi Penegakan Hukum. Jakarta : PT.Raja Grafindo Persada.

\section{Jurnal}

Eddy OS Hieriej. 2013.“Pengembalian Aset Kejahatan”, Jurnal Opinio Juris. Vol 13 Mei- Agustus.

Ismansyah.2013.Penerapan dan Pelaksanaan Pidana Uang Pengganti dalam TPK. http:/lejournal. unp.ac.id/index.php/jd/article/viewFile/1137/972.

D.Saputra Aji. Kajian Teori Kebijakan Publik. UNY.ac.id. E-jurnal Print.

Ismail Rumadan.Pengelolaan Keuangan Negara dan Penerapan Hukum dalam Tindak Pidana Korups (The State Finance Management and Law Practice In Corruption).Indonesian Journal Of Legislation Vol 10 No 4 Desember 2013.

Jhon I Otalor, Ofiafoh Eiya. Combating Corruption In Nigeria : The Role Of The Public Sector. Auditor Research Journal of Finance and Accounting, Vol 1 No 4, 2013, www.iiste.org

\section{Undang-undang}

Undang-Undang Nomor 1 Tahun 2004 tentang Perbendaharaan Negara

Undang-undang Nomor 16 Tahun 2004 tentang Kejaksaan RI

Undang-undang Nomor 31 Tahun 1999 jo Undang-Undang Nomor 20 Tahun 2001

\section{Website}

$\underline{\text { www.kejaksaan.co.id }}$

kpk.go.id 